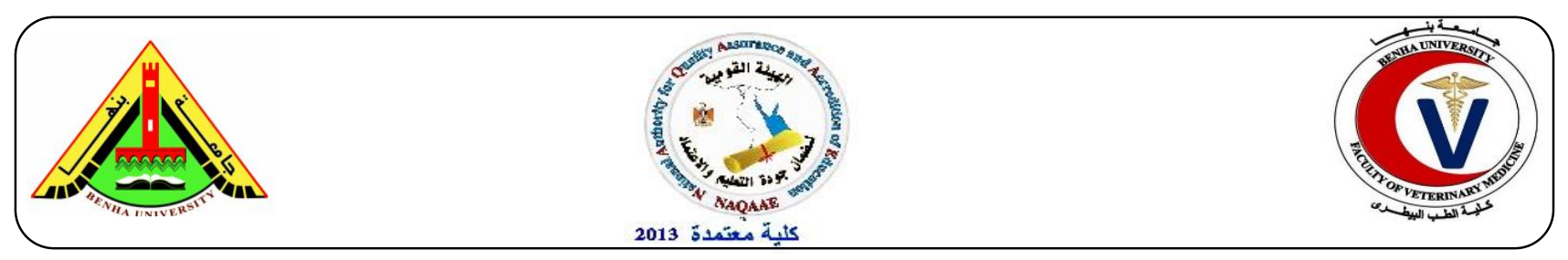

\title{
Detection of Some Heavy Metals in Fresh and Salted Fish
}

\author{
Elrais, Amina, M. ${ }^{1}$; Hassanien, Faten, S. ${ }^{1}$; Hassan, M.A. ${ }^{1}$; El-Zahaby, Dina, I. ${ }^{2}$ and Latif, H.M. ${ }^{1}$ \\ ${ }^{l}$ Food Hygiene and Control Department, Faculty of Veterinary Medicine, Benha University, Egypt. \\ ${ }^{2}$ Meat hygiene, animal research institute Shebien El-kom Branch.
}

\begin{abstract}
A B S T R A C T
Eighty random samples of fresh and salted fish represented by fresh Sardine and salted Sardine \& fresh Mugil cephalus and salted Mugil cephalus (20 of each) were collected from various fish markets in Menoufia governorate, Egypt. The collected samples were examined for determination of their mercury and lead levels on the basis of wet weight $(\mathrm{mg} / \mathrm{kg})$. The mean values of mercury level in the examined samples were $0.98 \pm 0.07 \& 1.26 \pm 0.13$ for fresh and salted sardine fish and $0.69 \pm 0.04$ $\& 1.59 \pm 0.16$ for fresh and salted Mugil cephalus, respectively. Accurately 50\%, 65\%, 40\%, 80\% of the examined samples of fresh sardine, salted sardine, fresh Mugil cephalus and salted Mugil cephalus were unaccepted according to E.O.S. The mean value for the lead levels $\mathrm{mg} / \mathrm{kg}$ in the examined samples were $0.32 \pm 0.03 \& 0.49 \pm 0.05$ for fresh \& salted sardine and $0.26 \pm 0.02 \& 0.65 \pm 0.08$ for fresh and salted Mugil cephalus, respectively. Accurately 35\%, 45\%, 30\%, 65\% of the examined samples of fresh \& salted Sardine and fresh \& salted Mugil cephalus were unaccepted according to E.O.S.
\end{abstract}

Keywords: Sardine, Mugil Cephalus, fresh, salted, mercury, lead.

(http://www.bvmj.bu.edu.eg) (BVMJ-35(2): 169-177, 2018)

\section{INTRODUCTION}

Fish is a desirable and highly nutritive food. It is considered as a rich source of calcium, phosphorous and vitamins, long-chain omega3 polyunsaturated fatty acids, DHA (Docosahexaenoic acid) and Eicosapentaenoic acid which are associated with many health benefits (Mohamed et al., 2015).

Salting is one of the earliest and most widespread preservation technique practiced by man (Wheaton and Lawson, 1985), low production cost and its ability to be combined with other methods in order to satisfy consumer's habit and requirements (Berhimpon et al., 1991). It is well known that fish salting is a process which aims to reach the saline equilibrium between fish muscles and the surrounding salt solution in a specific time (Zugarramurdi and Lupin, 1980). Feseakh is a traditional Egyptian fish dish consisting of fermented salted and dried mullet, of the Mugil family, a saltwater fish that lives in both the Mediterranean and the Red Seas (Yosef and Gomaa, 2011).

On other hand, fish have the ability to accumulate heavy metals in their tissues by the absorption along the gill surface and gut tract wall to higher levels several hundred times more than the concentration of metals in their 
surrounding water medium (Nammalwar, 1983).

The effects of heavy metals on human health and environment are of great interest today, especially for aquatic food products (Ranau et al., 2001 and Sasmaz and Yaman, 2006).Toxic elements can be very harmful even at low concentration when ingested over a long time period. The essential metals can also produce toxic effects when their intake is excessive (Celik and Oehlenschlager, 2007).

Therefore, it was important and necessary to conduct this study to determine the concentrations of mercury and lead as heavy metals in fresh \& salted Sardine and Mugil cephalus fish marketed in Menoufia governorate and comparing the levels of pollution with E.O.S. (2010).

\section{Materials and methods}

\subsection{Collection of samples:}

Eighty random samples of fresh and salted fish represented by fresh Sardine, salted Sardine, fresh Mugil cephalus and salted Mugil cephalus (20 of each) as were collected at different times from various fish markets in Menoufia governorate, Egypt. All collected samples were kept in a separated sterile plastic bag and preserved in an ice box then transferred to the laboratory with a minimum limit of delay for analysis of mercury $(\mathrm{Hg})$ and lead $(\mathrm{Pb})$ levels.

\subsection{Determination of heavy metals:}

The collected samples were examined for determination of their mercury and lead levels on the basis of wet weight $(\mathrm{mg} / \mathrm{Kg})$.

\subsubsection{Preparation of collected samples (Lars,} 2003):

Washing of equipment is an important process to avoid contamination with the analyzed elements. Glass wares and vessels were thoroughly cleaned with deionized water and soaked in hot diluted $\mathrm{HNO}_{3}(10 \%)$ for 24 hours and rinsed several times with deionized water and dried to ascertain that all the equipment were metal free. While, the digestion vessels were soaked in water and soap for 2 hours and then rinsed several times with tap water. They were rinsed once with distilled water, once with the mixture $(250 \mathrm{ml}$ deionized water, $200 \mathrm{ml}$ conc. $\mathrm{HCl}$ and $80 \mathrm{ml}$ $\mathrm{H}_{2} \mathrm{O}_{2}$ ) and once with $10 \% \mathrm{HNO}_{3}$.

Finally, all containers were thoroughly washed with deionized water and air-dried in incubator away from any contamination or dust.

2.2.2. Digestion technique (Staniskiene et al., 2006):

Accurately, 1g of each sample were macerated by sharp scalpel and digested by $10 \mathrm{ml}$ of digestion mixture $(60 \mathrm{ml}$ of $65 \%$ Nitric acid and $40 \mathrm{ml}$ of $70 \%$ perchloric acid) in screw capped tube after maceration. In regard to mercury, 0.5 gm. of macerated sample was digested in $10 \mathrm{ml}$ of concentrated $\mathrm{H}_{2} \mathrm{SO}_{4} / \mathrm{HNO}_{3}$ solution (1:1).

The tubes were tightly closed and the contents were vigorously shaken and allowed to stand overnight at room temperature. Moreover, the tubes were heated for 4 hours in water bath starting from $60^{\circ} \mathrm{C}$ till reach $110^{\circ} \mathrm{C}$ ensure complete digestion of the samples.

The digestion tubes were vigorously shaken at 30 minutes intervals during the heating period. The tubes were then left to cool at room temperature and diluted with $1 \mathrm{ml}$ deionized water $(30 \%)$ as well as reheated in water bath at $70^{\circ} \mathrm{C}$ to ensure complete digestion of the samples. At this point, all organic matrixes have been destroyed.

Each tube was diluted with deionized water till reach $25 \mathrm{ml}$ and the digest was filtered with Whattman filter paper No. 42. The filtrates were collected in Pyrex glass test tubes capped with polyethylene film and kept at room temperature until analyzed for their mercury and lead concentrations.

2.2.3. Preparation of blank and standard solutions (Andreji et al., 2005): 
Instrumental procedures for various analyses were based on those suggested in the operator manual of the Flame Atomic Absorption Spectrophotometer (VARIAN, model AA240 FS, Australia). However, blank and standard solutions were prepared in the same manner as applied for wet digestion and by using the same chemicals.

Blank solution consisted of 10 parts of nitric acid and 1 part of $\mathrm{H}_{2} \mathrm{O}_{2}$ then was diluted with 25 parts of deionized water and filtered. The blank was used to determine the metal contamination which may be present in the chemicals and its value was discounted from the end calculated results.

Furthermore, the standard solutions using pure certified metal standards at different strengths were prepared by 10 parts of nitric acid and 1 part of $\mathrm{H}_{2} \mathrm{O}_{2}$ then was diluted with 25 parts of deionized.

\subsubsection{Analysis:}

The digest, blanks and standard solutions were aspirated by Atomic Absorption Spectrophotometer and analyzed for their concentrations of such elements. The apparatus has an auto sampler, digital absorbance and concentration readout capable of operating under the conditions recommended by the instrument instructions.

\subsubsection{Quantitative determination of heavy} metals:

Absorbency of mercury and lead was directly recorded from the digital scale and their concentrations were calculated according to the following equation:

\section{Where,}

$$
\mathrm{C}=\mathrm{R} \times(\mathrm{D} / \mathrm{W})
$$

$\mathrm{C}=$ Concentration of the element (wet weight).

$\mathrm{R}=$ Reading of digital scale of AAS.

$\mathrm{D}=$ Dilution of the prepared sample.

$\mathrm{W}=$ Weight of the sample.
N. B. The concentration of each element in the blank solution was also calculated and subtracted from each analyzed sample.

\section{RESULTS}

The study revealed that percentage of fresh sardine contaminated with mercury is $65 \%$ (13 samples), for salted sardine $75 \%$ (15 samples), for fresh M.cephalus 60\% (12 samples) and for salted M.cephalus $85 \%$ (17 samples), Table (1).

It is evident from the results recorded in Table (2) that the concentration of mercury in fresh sardine ranged from 0.25 to $1.52 \mathrm{mg} / \mathrm{kg}$, with an average of $0.98 \pm 0.07 \mathrm{mg} / \mathrm{kg}$ while, salted sardine ranged from 0.33 to $1.91 \mathrm{mg} / \mathrm{kg}$, with an average of $1.26 \pm 0.13 \mathrm{mg} / \mathrm{kg}$. Moreover, the concentration of mercury in fresh M.cephalus ranged from 0.21 to 1.18 $\mathrm{mg} / \mathrm{kg}$, with an average of $0.69 \pm 0.04 \mathrm{mg} / \mathrm{kg}$ while salted M.cephalus ranged from 0.42 to $2.37 \mathrm{mg} / \mathrm{kg}$, with an average of $1.59 \pm$ $0.16 \mathrm{mg} / \mathrm{kg}$.

The study revealed that percentage of fresh sardine contaminated with lead is $55 \%$ (11 samples), for salted sardine $70 \%$ (14 samples), for fresh M.cephalus 45\% (9 samples) and for salted M.cephalus 75\% (15 samples), Table (4)

It is evident from the results recorded in Table (5) that the concentration of lead in fresh sardine ranged from 0.13 to $0.61 \mathrm{mg} / \mathrm{kg}$, with an average of $0.32 \pm 0.03 \mathrm{mg} / \mathrm{kg}$ while, salted sardine ranged from 0.18 to $0.90 \mathrm{mg} / \mathrm{kg}$, with an average of $0.49 \pm 0.05 \mathrm{mg} / \mathrm{kg}$. Moreover, the concentration of lead in fresh M.cephalus ranged from 0.09 to $0.47 \mathrm{mg} / \mathrm{kg}$, with an average of $0.26 \pm 0.02 \mathrm{mg} / \mathrm{kg}$ while, salted M.cephalus ranged from 0.23 to $1.18 \mathrm{mg} / \mathrm{kg}$, with an average of $0.65 \pm 0.08 \mathrm{mg} / \mathrm{kg}$. 
Elrais et al. (2018). BVMJ-35(2): 169-177

Table 1: Numbers and percentages of fresh and salted fish contaminated with mercury $(n=20)$.

\begin{tabular}{lllll}
\hline Fish species & Fresh & & Salted & \\
& No. & $\%$ & No. & $\%$ \\
\hline Sardine & 13 & 65 & 15 & 75 \\
M. cephalus & 12 & 60 & 17 & 85 \\
\hline
\end{tabular}

Table 2: Statistical analytical results of mercury levels $(\mathrm{mg} / \mathrm{kg})$ in the examined samples of fresh and salted fish $(n=20)$.

Status

Fresh

Salted

Fish

\begin{tabular}{lcccccc} 
& Min & Max & Mean \pm S.E $^{*}$ & Min & Max & Mean \pm S.E $^{*}$ \\
\hline Sardine & 0.25 & 1.52 & $0.98 \pm 0.07^{\mathrm{a}}$ & 0.33 & 1.91 & $1.26 \pm 0.13^{\mathrm{A}}$
\end{tabular}

$\begin{array}{lllllll}\text { M.cephalus } & 0.21 & 1.18 & 0.69 \pm 0.04^{\mathrm{b}} & 0.42 & 2.37 & 1.59 \pm 0.16^{\mathrm{B}}\end{array}$

S.E $E^{*}=$ standard error of mean

N.B. Means with different superscripts were significantly differed $(\mathrm{P}<0.05)$

Table 3: Acceptability of the examined samples of fresh and salted fish based on their levels of mercury $(n=20)$.

\section{Accepted Samples Unaccepted Samples}

Fish species

\begin{tabular}{|c|c|c|c|c|c|}
\hline & $\operatorname{MRL}(\mathrm{mg} / \mathrm{kg})^{*}$ & No. & $\%$ & No. & $\%$ \\
\hline Fresh Sardine & & 10 & 50 & 10 & 50 \\
\hline Salted Sardine & & 7 & 35 & 13 & 65 \\
\hline Fresh M.cephalus & 0.50 & 12 & 60 & 8 & 40 \\
\hline Salted M.cephalus & & 4 & 20 & 16 & 80 \\
\hline
\end{tabular}

* Maximum Residual Limit stipulated by Egyptian Organization for Standardization "EOS" (2010).

Table 4: Numbers and percentages of fresh and salted fish contaminated with lead $(n=20)$.

Fresh Salted

Fish species

\begin{tabular}{rcccc} 
& No. & $\%$ & No. & $\%$ \\
\hline Sardine & 11 & 55 & 14 & 70 \\
M. cephalus & 9 & 45 & 15 & 75 \\
\hline
\end{tabular}


Table 5: Statistical analytical results of lead levels $(\mathrm{mg} / \mathrm{kg})$ in the examined samples of fresh and salted fish $(n=20)$.

\begin{tabular}{lcccccc}
\hline \multicolumn{1}{c}{ Status } & \multicolumn{2}{c}{ Fresh } & \multicolumn{2}{c}{ Salted } \\
Fish & Min & Max & Mean \pm S.E & Min & Max & Mean \pm S.E $^{*}$ \\
\hline Sardine & 0.13 & 0.61 & $0.32 \pm 0.03^{\mathrm{a}}$ & 0.18 & 0.90 & $0.49 \pm 0.05^{\mathrm{A}}$ \\
& & & & & & \\
M.cephalus & 0.09 & 0.47 & $0.26 \pm 0.02^{\mathrm{b}}$ & 0.23 & 1.18 & $0.65 \pm 0.08^{\mathrm{B}}$ \\
& & & & & & \\
\hline
\end{tabular}

S.E $E^{*}=$ standard error of mean

N.B. Means with different superscripts were significantly differed $(\mathrm{P}<0.05)$

Table 6: Acceptability of the examined samples of fresh and salted fish based on their levels of lead $(n=20)$.

Accepted Samples Unaccepted Samples

Fish species

\begin{tabular}{|c|c|c|c|c|c|}
\hline & $\operatorname{MRL}(\mathrm{mg} / \mathrm{kg})^{*}$ & No. & $\%$ & No. & $\%$ \\
\hline Fresh Sardine & & 13 & 65 & 7 & 35 \\
\hline Salted Sardine & & 11 & 55 & 9 & 45 \\
\hline & 0.30 & & & & \\
\hline Fresh M.cephalus & & 14 & 70 & 6 & 30 \\
\hline Salted M.cephalus & & 7 & 35 & 13 & 65 \\
\hline
\end{tabular}

* Maximum Residual Limit stipulated by Egyptian Organization for Standardization "EOS" (2010). aquatic sediments through the bacterial

\section{DISCUSSION}

Monitoring tissues of fish for contamination enables evaluation of pollution effects on fish, to detect metal concentrations in fish hazardous to human consumption and to take appropriate action for the preservation of the public health and the environment and socioeconomic reasons (Osman and Kloas, 2010).

\subsection{Mercury:}

Mercury $(\mathrm{Hg})$ is one of the most important pollutants both because of its effect on marine organisms and it is potentially hazardous to humans. Methylmercury, which is formed in methylation of organic mercury, is toxic chemicals compound of mercury, in fact, nearly all of the mercury in fish muscles occurs as Methylmercury (Joiris et al., 1999). Methyl mercury affects the kidneys and also the central nervous system, particularly during development, as it crosses both the blood-brain barrier and placenta (Clarkson, 2002).

The obtained result of fresh sardine is higher than that recorded by Falco et al. (2006) (0.07$0.09 \mathrm{mg} / \mathrm{kg}$ ) and lower than that recorded by Soliman (2006) $(0.287 \pm 0.910 \mathrm{mg} / \mathrm{kg})$.

The mean value of $\mathrm{Hg}$ in muscles of salted sardine is higher than that recorded by Sallam and El-Gazzar (1997) $(0.253 \pm 0.037 \mathrm{mg} / \mathrm{kg})$. 
The present result of fresh M.cephalus is nearly parallel to that reported by Soliman (2006) $(0.334 \pm 0.102 \mathrm{mg} / \mathrm{kg})$ but lower than those recorded by Abd El-Fatah and Salem (2007) and Abd El-kader et al. (1993).

Lower results of $\mathrm{Hg}$ in muscles of salted M.cephalus were recorded by Sallam and ElGazzar (1997) (0.212 \pm 0.7$)$ and Salah El-Dien et al. (2005) $(0.143 \pm 0.0179 \mathrm{mg} / \mathrm{kg})$.

According to Egyptian Organization of Standardization E.O.S. (2010) which recommended that the maximal permissible limits for mercury is $0.50 \mathrm{mg} / \mathrm{kg}$ in fish, the number of un-accepted samples of fresh Sardine, salted sardine, fresh M.cephalus and salted M.cephalus were $10,13,8$ and 16 represented as 50\%, 65\%, $40 \%$ and $80 \%$, respectively (Table, 3 ).

\subsection{Lead:}

Lead is a wide spread environmental contaminant worldwide (Hozhabri et al., 2004), and the accumulation of such trace element in aquatic organisms may lead to serious health problems through the food chain (Ip et al., 2005). Consumption of fish contaminated with lead is the most likely route for human (Wang et al., 2005). Fish products may be contaminated with lead during manufacturing and processing via using of contaminated utensils and premises (Sorenson, 2003).

The present result of fresh sardine is nearly parallel to that reported by Ohaida (2014) $(1.18 \pm 0.48 \mathrm{mg} / \mathrm{kg})$ but lower than that recorded by Canli and Atli (2003) (5.57 \pm 1.03 $\mathrm{mg} / \mathrm{kg}$ ) and higher than that reported by Falco et al. (2006) (0.01- $0.08 \mathrm{mg} / \mathrm{kg})$.

The obtained results of lead in muscles of salted sardine agree with those recorded by Sallam and El-Gazzar (1997) (0.316 \pm 0.043 $\mathrm{mg} / \mathrm{kg}$ ) and Daoud and Abd El-Aziz (2002)
$(0.275 \pm 0.044 \mathrm{mg} / \mathrm{kg})$ but lower than that recorded by El-kewaiey et al. (2011) $(2.097 \pm 0.224 \mathrm{mg} / \mathrm{kg})$.

The present result of fresh M.cephalus is nearly parallel to those reported by Yosef and Gomaa (2011), El-Atabany (1995), Abd Elkader et al. (1993) but higher results were recorded by Canli and Atli (2003) and Abd ElFatah and Salem (2007) and lower result was recorded by Mohamed, et al. (2016).

The obtained results of lead in muscles of salted M.cephalus agree with that recorded in muscles of M.cephalus salted by analytical salt $(0.448 \pm 0.081 \mathrm{mg} / \mathrm{kg})$ and lower than that salted by industrial salt $(1.142 \pm 0.154 \mathrm{mg} / \mathrm{kg})$ Yosef and Gomaa (2011).

Meanwhile the results recorded by Salah ElDien et al. (2005) revealed a higher residual level, but the lower results were reported by Sallam and El-Gazzar (1997).

According to Egyptian Organization of Standardization E.O.S. (2010) which recommended that the maximal permissible limits for lead is $0.30(\mathrm{mg} / \mathrm{kg})$ in fish, the number of un-accepted samples of fresh Sardine, salted Sardine, fresh M.cephalus and salted M.cephalus were 7, 9, 6 and 13 represented as 35\%, 45\%, 30\% and $65 \%$, respectively (Table, 6).

The low mean values of lead may be attributed to low binding rate of lead to sulfhydryl groups in muscle as well as low solubility of lead salts (Moore and Ramamoorthyl, 1984).

In general, the examined samples of salted fish contained higher mercury and lead levels than those of fresh fish these results were probably credited to the usage of impure salts during salting process (Yosef and Gomaa, 2011).

The using of fish from uncontaminated water, controlling the industrial and agriculture effluents into lakes and surface water; and the 
using of hygienic salts in the salting process of fish are the preventive measures to produce a hygienic salted fish for human consumption. Moreover, regularly analyzing and testing of marketed seafood for heavy metals concentrations to insure their safety for human consumption is highly recommended to avoid one of the most hazardous sources of metal pollutions in food.

\section{Conclusion}

The present study declared that some fresh water fish and salted fish samples were collected at different times from various fish markets in Menoufyia governorate, Egypt, were contaminated with mercury and lead in higher values exceeding the Safe Permissible Limits for human consumption.

\section{REFERENCES}

Abd El-Fatah-Noha, R.M. and Salem-Ghada, S.E. (2007): Heavy metal residues in some fresh Egyptian fishes. Vet. Med. J., Giza. 55(3): 787-798, Egypt.

Abd El-kader, M.A.; Tork, I.Y.; Amine, M.A. and Aref, M.A. (1993): Heavy metal pollution in fish ponds. Zag. Vet. J., 21(2): 116-125, Egypt.

Andreji, J.; Stranai, Z.; Massonyl, P. and Valent, M. (2005): Concentration of selected metal in muscle of various fish species. J. Environ. Sci. Heal. 40(4): 899-912.

Berhimpon, S.; Souness, R.A.; Driscoll, R.H.; Buckle, K.A. and Edwards, R.A. (1991): Salting behavior of yellow tail (Trachurusmuscullochi Nichols). J. Food Protect. Preserv. 15(2): 101-114.

Canli, M. and Atli, G. (2003): The relationships between heavy metal $(\mathrm{Cd}$, $\mathrm{Cr}, \mathrm{Cu}, \mathrm{Fe}, \mathrm{Pb}, \mathrm{Zn}$ ) levels and the size of six Mediterranean fish species. Environmental Pollution, 121(1): 129136. Doi: 10.1016/s02697491(02)00194-x.

Celik, U. and Oehlenschlager, J. (2007): High contents of Cadmium, lead, zinc and copper in popular fishery products sold in Turkish supermarkets. Food Control, 18: 258-261.

Clarkson, T. (2002): The three modern faces of mercury. Environ. Health Perspect., 110: 11-23.

Daoud-Jehan, R. and Abd El-Aziz, A.H.B. (2002): Determination of some heavy metal residues in salted and smoked fishes. Vet. Med. J. Giza 50: 547-556, Egypt.

Egyptian Organization for Standardization "EOS" (2010): Maximum Levels for certain contaminants in foodstuffs. No 7136/2010. Egyptian Standards, Ministry of Industry, Egypt.

El-Atabany, A.l. (1995): Cadmium and lead residues in some food animals and fish tissues at Manzala, Dakahlia. Zag. Vet. J., 23(5): 90-96, Egypt.

El-Kewaiey, I.A.; Ali-Omima, I. and SalehOmima, A. (2011): Incidence of heavy metals residues in salted and smoked fish products. Assiut vet. Med. J., 57(131): 92-108, Egypt.

Falco, G.; Llobet, J.; Bocio. A. and Domingo, J. (2006): Daily Intake of Arsenic, Cadmium, Mercury, and Lead by Consumption of Edible Marine Species. J. Agric. Food Chem., 54: 6106-6112.

Hozhabri, S.; White, F.; Rahbor, M.H.; Agboatwalla, M. and Luby, S. (2004): Elevated blood levels among children in 
a fishing community, Karachi, Pakistan. Arch Environ. Health 59(1): 37-41.

Ip, C.C.M.; Li, X.D.; Zhang, G.; Wong, C.S.C. and Zhang, W.L. (2005): Heavy metal and $\mathrm{Pb}$ isotopic compositions of aquatic organisms in the Pearl River Estuary, South China. Environ. Pollut. 138(3): 494-504.

Joiris, C.R. and Holsbeek, L. (1999): Total and methylmercury in sardines Sardinella aurita and Sardina pilchardus from Tunisia. Mar. Pollut. Bull., 38(3): 188192.

Lars, J. (2003): Hazards of heavy metal contamination. British Med. Bull., 68: 167-182.

Mohamed, A.A.; Galal, A.A. and Elewa, Y.H. (2015): Comparative protective effects of royal jelly and cod liver oil against neurotoxic impact of tartrazine on male rat pups brain. ActaHistochem, 117: 649-658.

Mohamed-Amany, A.R.; Tharwat, A.E.S. and Khalifa, H.A. (2016): Estimation of organochlorine pesticides and heavy metal residues in two species of mostly consumed fish in Sharkia governorate, Egypt. Jap. J. Vet. Res., 64(2): 233-241.

Moore, J.W. and Ramamoorthy, S. (1984): Heavy metals in natural waters. Applied monitoring and Impact assessment, U.S.A.

Nammalwar, P. (1983): Heavy metal pollution in the marine environment. Sci. Rep., 20(3): 158-160.

Ohaida, A.M I. (2014): Accumulation of some heavy metals in different Libyan fish species from fresh water and marine environments. J. Animal and Poultry Prod., Mansoura Univ., 5(7): 423-433.
Osman, A.G. and Kloas, W. (2010): Water quality and heavy metal monitoring in water, sediments, and tissues of the African catfish Clarias gariepinus (Burchell, 1822) from the river Nile, Egypt. J. Environ. Protect., 1(4): 389400.

Ranau, R.; Oehlenschlager, J. and Steinhart, H. (2001): Aluminium levels of fish fillets backed and grilled in aluminium foil. Food Chemistry, 73: 1-6.

Salah El-Dien, W.M.; Makhouf-Manal, M. and Abd El-Fattah, M.E (2005): Residual analysis of some heavy metals in salted fish (Feseakh) in Sharkia governorate. Zag. Vet. J., 33(1): 248-254, Egypt.

Sallam, Kh.I. and El-Gazzar, M.M. (1997): Heavy metal residues in salted and smoked fish marketed at Zagazig City. Alex. J. Vet. Sci., 13(5): 525-532, Egypt.

Sasmaz, A. and Yaman, M. (2006): Distribution of chromium, nickel, and cobalt in different port species and soil in mining area of keban. Turkey communications in soil. Science and Plant Analysis, 37: 1845-1857.

Soliman-Zienab, I. (2006): A Study of Heavy Metals Pollution in Some Aquatic Organisms in Suez Canal in Port- Said Harbour. J. App. Sci. Res., 2(10): 657663.

Sorensen E.M. (2003): Metal Posioning in fish. A text book, 2nd Ed.; CRC press, Inc., Boca Raton, Florida, U.S.A.

Staniskiene, B.; Matusevicius, P.; Budreckiene, P. and Skibniewska, K.A. (2006): Distribution of heavy metals in tissues of freshwater fish in Lithuania. Polish J. Environ Studies, 15(4): 585591. 
Wang, S.T.; xing, B. and Toe, S. (2005): Health risks of heavy metals of heavy metals to the general public in Tianjin, China via consumption of vegetables and fish. Sci. Total Environ., 35(1): 2837.

Wheaton, F.W. and Lawson, T.B. (1985): Other preservation method. In: "Processing Aquatic Food Products": Wheaton, F.W. and Lawson, T.B. Eds John Wiley \& Sons Inc. New York, USA.

Yosef, T.A. and Gomaa-Ghada, M. (2011): Assessment of Some Heavy Metal Contents in Fresh and Salted (Feseakh) Mullet Fish Collected from El- Burullus Lake, Egypt. J. Amer. Sci., 7(10): 137144. (ISSN: 1545-1003). http://www.americanscience.org.

Zugarramurdi, A. and Lupin, H.M. (1980): A model to explain observed behavior on fish salting. J. Food Sci., 45(5): 13051311. 